\title{
EFFECT OF A METAL PRIMER ON THE BOND STRENGTH OF THE RESIN-METAL INTERFACE
}

\author{
EFEITO DE UM PRIMER PARA METAIS SOBRE A FORÇA DE UNIÃO \\ DA INTERFACE METAL-RESINA
}

Anderson Pinheiro de FREITAS ${ }^{1}$, Paulo Afonso Silveira FRANCISCONI ${ }^{2}$

1- Graduate Sudent (Doctor Degree), Dept. of Operative Dentistry - Bauru Dental School - USP.
2- Associated Professor, Dept. of Operative Dentistry - Bauru Dental School - USP.

Corresponding address: Anderson Pinheiro de Freitas - Departamento de Materiais Dentários / FOB - USP. - Al. Dr. Octávio Pinheiro Brizolla, 9-75 - Bauru-SP. - CEP: 17.012-901. Phone: (014) 235-8261 / 235-8263 - Fax: (014) 226-1495 - e-mail 1: andersonpfreitas@ig.com.br e-mail 2: pasf@fob.usp.br

Received: July 12, 2003 - Return for modification: October15, 2003 - Accepted: December 12, 2003

\begin{abstract}

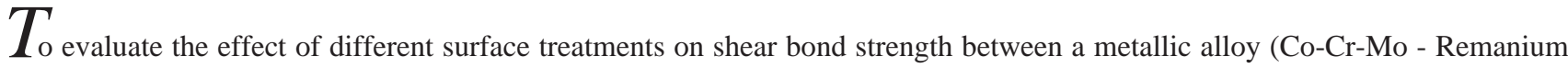
$\mathrm{CD}$ ) and a resin cement (Rely $\mathrm{X}^{\mathrm{TM}}$ ) and to evaluate the mode of fracture after testing, forty couples of metallic-alloy disks were melted, regularized, polished, submitted to four thermal cycles (Vacuum, $960^{\circ} \mathrm{C}, 8$ minutes) and randomly separated into four groups. Each group received a different type of treatment: Group PSP: Polished with sandpaper 600; Group PCP: Polished with sandpaper 600 and application of the metal primer Alloy Primer (Kuraray); Group JSP: Sandblasted with 100 $\mu$ m aluminum oxide; Group JCP: Sandblasted with 100mm aluminum oxide and treated with a metal Primer. The groups were cemented and stored in distilled water at $37^{\circ} \mathrm{C}$ for 36 hours and submitted to the shear bond strength test. The mean and standard deviation (in Kgf/ $\mathrm{cm}^{2}$ ) obtained for each group was: PSP 4.0/0.4; PCP 88.9/33.6; JSP 163.2/27.6; JCP 144.5/54.0. After the statistical analysis the authors concluded that: the highest values were obtained for the sandblasted groups (JSP, JCP), regardless of the primer application; the Alloy Primer increased the retention between the Rely X cement and the polished surface of the Co-Cr-Mo alloy, yet its bond strength was not greater than that obtained with sandblasting; all specimens showed adhesive failures in the tested interface.

UNITERMS: Resin cement; Metallic alloy; Surface treatment; Shear bond strength.
\end{abstract}

\footnotetext{
RESUMO

$P$ Para avaliar o efeito de diferentes tratamentos superficiais sobre a resistência ao cisalhamento da união entre uma liga metálica (Co-Cr-Mo - Remanium CD) e um cimento resinoso (Rely $\mathrm{X}^{\mathrm{TM}}$ ) e analisar o tipo de fratura durante a separação dos espécimes, quarenta pares de discos metálicos foram fundidos, regularizados e polidos, submetidos a quatro ciclos térmicos (vácuo, $960^{\circ} \mathrm{C}, 8$ minutos) e divididos aleatoriamente em quatro grupos. Cada grupo recebeu um tipo de tratamento: Grupo PSP: Polimento com lixa d’água $N^{\circ}$ 600; Grupo PCP: Polimento com lixa 600 e aplicação do condicionador metálico Alloy Primer (Kuraray); Grupo JSP: Jato de óxido de alumínio de $100 \mu \mathrm{m}$, e Grupo JCP: Jato de óxido de alumínio de 100mm, e aplicação do Alloy Primer. Os grupos foram cimentados e armazenados em água destilada a $37^{\circ} \mathrm{C}$ por 36 horas e submetidos ao ensaio de resistência ao cisalhamento. A média e o desvio padrão (em kgf/ $\mathrm{cm}^{2}$ ) obtidos para cada grupo foram: PSP 4,0/0,4; PCP 88,9/33,6; JSP 163,2/27,6; JCP 144,5/54,0. Após a análise estatística os autores concluíram que: os maiores valores foram produzidos pelos grupos jateados (JSP, JCP), independentemente da aplicação do primer; o Alloy Primer aumentou a retentividade entre o cimento Rely X e a superfície polida da liga de Co-Cr-Mo, entretanto sua força de união não superou a alcançada através do jateamento; todos os espécimes apresentaram falha adesiva na interface testada.

UNITERMOS: Cimento resinoso; Liga metálica; Tratamento superficial; Resistência ao cisalhamento.
} 


\section{INTRODUCTION}

During the last years several works were accomplished on the increase of the bond strength of resins to metals, mainly through surface treatment of metallic alloys. Nowadays, several chemical systems of adhesion for metallic alloys have been introduced in the market, most containing an acid monomer able to adhere either to the metal or to the enamel ${ }^{8}$.

Several alloys can be used for the development of adhesive bridges with quite satisfactory clinical behavior, since they are treated appropriately. The types of surface treatments applied to metals can vary according to its composition and pattern of granulation. Due to its high elasticity module in relation to gold, basic metal alloys like $\mathrm{Ni}-\mathrm{Cr}$ are favorite for making of adhesive bridges ${ }^{2}$, being the most utilized and presenting the best results in tests ${ }^{9}$; however, they are contraindicated for use in patients sensitive to nickel ${ }^{6}$, main component of this alloy. Co-CrMo can substitute these alloys, apparently without affecting the durability or the clinical behavior of the restorations ${ }^{5}$.

The success of an adhesive bridge does not depend only on the union between the metal and the resin, but also on proper dental reduction, which supplies retention and stability to the metallic structure and compatibility with the bite forces to which the prosthesis will be submitted ${ }^{9}$. However, prosthesis presenting a structure deficiently elaborated or fragile will be prone to failure; therefore, an appropriate treatment plan and the bond between their components and the tooth to be restored are fundamental.

The literature shows that several doubts still remain concerning the bonding in adhesive bridges and the best treatment to be applied to the metallic surface, in this case, to the Co-Cr-Mo alloys, due to the lack of studies regarding its union to the resin cements and several materials for esthetic facets in prosthesis.

The present work aimed at evaluating the effect of different surface treatments applied in a Co-Cr-Mo alloy on the shear bond strength of the union between the metallic alloy and a resin cement, and to analyze the type of fracture occurring during separation of the specimens.

\section{MATERIALAND METHODS}

\section{Materials}

For accomplishment of this study, a Co-Cr-Mo alloy (Remanium CD / Dentaurum), a metal primer (Alloy Primer / Kuraray), a resin cement (Rely $\mathrm{X}^{\mathrm{TM}} / 3 \mathrm{M}$ ) and $100 \mu \mathrm{m}$ aluminum oxide were used. The main characteristics of the materials employed are described in the following Table 1.

\section{Methods}

Forty pairs of Co-Cr-Mo alloy disks were melted, being half constituted by a disk of $10 \mathrm{~mm}$ and half of $12 \mathrm{~mm}$ of diameter, both with $2 \mathrm{~mm}$ of thickness. Those disks present loops in one of the faces to facilitate the handling of the specimens. Two cemented disks of different diameters represented a specimen.

After casting, the metallic disks were cleaned with blasting with aluminum oxide, regularized and polished with sandpaper 600 , in order to eliminate possible variations in surface texture.

All metallic disks obtained were submitted to 4 thermal cycles, under vacuum, at $960^{\circ} \mathrm{C}$ to simulate firing of the porcelain, with consequent formation of a superficial oxide film. Afterwards, the disks were washed in running water and in distilled water in an ultrasonic device for 2 minutes.

The disks with 12-mm diameter were fastened in a base of epoxy resin to allow adaptation to the shear device; afterwards, the specimens were randomly divided in four groups with ten specimens. Each group received a type of treatment in the surface to be cemented, as follows:

Group PSP (Polished without primer): Polished with sandpaper 600 (Control group).

Group PCP (Polished with primer): Polished with sandpaper 600 and surface oxidation, with application of the conditioning agent for metals Alloy Primer (Kuraray - Japan).

Group JSP (Sandblasted without primer): Sandblasted with $100 \mu \mathrm{m}$ aluminum oxide to $75 \mathrm{lb}$ of pressure, at a distance of $5 \mathrm{~cm}$, in right angle for 1 minute and cleaned for 2 minutes with distilled water in ultrasonic device.

Group JCP (Sandblasted with primer): Sandblasted with $100 \mu \mathrm{m}$ aluminum oxide to 75lb of pressure, at a distance of

TABLE 1- Specifications of the alloy, primer and cement employed

\begin{tabular}{|c|c|c|c|}
\hline Material & Manufacturer & Composition & Batch \\
\hline Remanium ${ }^{\circledR}$ CD / & Dentaurum & Co-Cr-Mo & 918444 \\
\hline Alloy Primer & Kuraray Medical inc.Japan & (MDP) (VBATDT) Acetone & 104AJ $10 / 2003$ \\
\hline Rely $X^{\mathrm{TM}}$ & 3M Dental Products USA. & (Bis-GMA) (TEGDMA) & \\
\hline resin Cement & & Zirconium / silica - 1,5 $\mu \mathrm{m}$ & CGCG 02 / 2004 \\
\hline
\end{tabular}

(MDP) 10 - methacryloyloxydecyl dihydrogen phosphate

(VBATDT) 6 - (4-vinylbenzyl-n-propyl) amino-1,3,5-triazine-2,4-dithione 
$5 \mathrm{~cm}$, in right angle for 1 minute and cleaned for 2 minutes with distilled water in ultrasound device, followed by Alloy Primer application.

All groups were cemented with the resinous cement Rely $\mathrm{X}^{\mathrm{TM}} / 3 \mathrm{M}$, under a load of $5 \mathrm{Kg}$ for 10 minutes, allowing the removal of excess cements and the marginal light-curing for 40 seconds in four positions. After this, they were stored in distilled water at $37^{\circ} \mathrm{C}$, protected from light during 36 hours, and then submitted to the tests of shear bond strength (SBS).

The specimens were adapted to the shear device through the base of the disk of larger diameter at the testing machine, through a metallic string contouring the border of the smaller disk. The force was applied until bond failure between the disks. The shear bond strength tests were conducted in a universal testing machine (Emic-Mem 2000) at a constant speed of $0.5 \mathrm{~mm} / \mathrm{min}$, with cell load of $500 \mathrm{kgf}$. The values in $\mathrm{Kgf} / \mathrm{cm}^{2}$ were obtained through the equation: $\mathrm{R}=\mathrm{F} / \mathrm{A}$. Were: $\mathrm{R}=\left(\mathrm{Kgf} / \mathrm{cm}^{2}\right) ; \mathrm{F}=$ rupture force $(\mathrm{kgf}) ; \mathrm{A}=$ bonding area $\left(0.785 \mathrm{~cm}^{2}\right)$.

Thereafter the surfaces of the disks were submitted to analysis in a stereoscopic magnifying glass to evaluate the type of failure and the final aspect of the metallic surface. Failure was classified as adhesive, if the failure occurred at the resin-metal interface; cohesive, when the resin cement was fractured; and mixed, a combination of adhesive and cohesive in resin cement.

\section{RESULTS}

The two-way analysis of variance (ANOVA) revealed a significant effect for the Sandblasting factor in any tested condition. The Primer factor presented a positive effect only on the polished surface, without significant effect on the Sandblasted specimens; there was no interaction between the two tested factors.

Comparison between the means of the groups with the Tukey test determined statistical equivalence between the groups JSP and JCP, both Sandblasted. They presented significant different between themselves and the polished groups (PSP and PCP). Besides, the polished groups presented statistical difference between themselves at a significant level $(\mathrm{p}<0.05)$ (Table 2).

\section{Type of failure}

In agreement with the findings observed through analysis in a stereoscopic magnifying glass with $8 x$ magnification, all specimens tested in this study presented adhesive failure in the resin-metal interface.

\section{DISCUSSION}

The literature presents several studies on the surface treatment of metallic alloys; these papers show that the minimal alteration on the composition of the alloy, cement or primer agent will lead to different shear bond strength (SBS) values. Even for the same type of alloy, generalizations cannot be made regarding the surface treatment, since there are many variations in the proportion of their constituent elements ${ }^{7}$.

The specimens of the PSP group (Polished without primer) presented the lowest SBS values, and among the ten specimens, only five could be tested, because the remaining failed during handling and inserting in the shear device. The polished surface presented a low union been this type of treatment not recommended by the literature since the appearance of adhesive bridges ${ }^{3,4}$.

In the PCP group (Polished with primer) there was an increase of more than twenty times in the average of the values when compared to the PSP group. This shows that the primer promoted an increase in the adhesion of the cement to the polished alloy through chemical means.

According to Matsumura, et al. ${ }^{8}$ (1997) complicated surface treatments will probably be substituted by the use of primers derived from thiol, in combination to cements with polymerization initiated by tri-n-buthyl-borane. According to Antoniadou, et al. ${ }^{1}$ (2000), utilization of the Alloy Primer is simple, fast and effective to increase the durability and the bond strength between resins and sandblasted metallic alloys; however, this bonding depends on the composition of the alloy. In 2001, Yoshida, et al. ${ }^{10}$

TABLE 2- Means results (m), standard deviation (sd) (expressed in $\mathrm{kgf} / \mathrm{cm}^{2}$ and in MPa) and comparison for the four groups, through the Tukey test

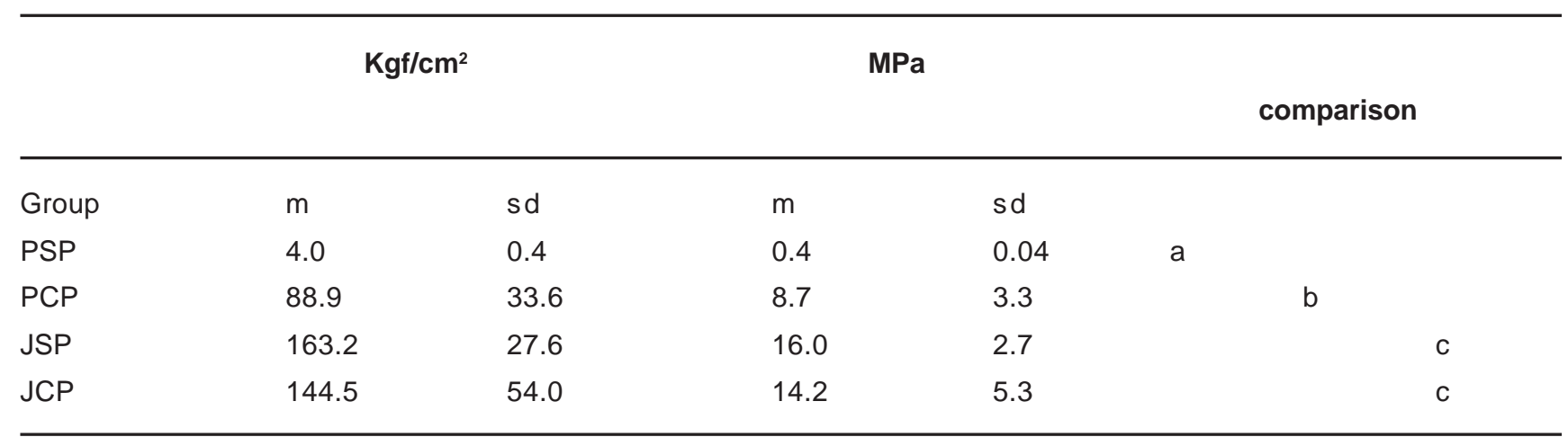

Means followed by different letters in the column indicate statistical difference at the $95 \%$ confidence level $(p<0.05)$. 
stated that the combined use of resin cements and an appropriate adhesive primer spares the use of complicated surface treatments during cementation of adhesive bridge, which minimizes the formation of marginal gaps and increases the clinical durability of restorations. According to these authors, the Alloy Primer containing the monomers VBATDT and MDP is effective to increase the bond strength between resins and basic alloys. MDP has an ester phosphate group that presents great chemical bonding with the surface layer of oxide of chrome formed in the surface of the cobalt-chrome, which can be highly reliable to promote better union of the cements to these alloys ${ }^{11}$.

Despite of this, the highest mean value of SBS was obtained for the sandblasted surface, regardless of the application of the metal primer. The JSP group (sandblasted with 100ìm aluminum oxide) and the JCP group (sandblasted with 100ìm aluminum oxide, with primer application) presented the highest SBS values, without significant difference between them. However, the JCP group presented a standard deviation that was two times larger than the JSP group.

According to Yoshida, et al. ${ }^{11}$ (1997) sandblasting with aluminum oxide on the surface of cobalt-chrome alloys favors the bonding between the chrome oxide and resin cements. Moreover, sandblasting promotes formation of surface irregularities in the metallic alloy, achieving micro-mechanical bonding when the cement flows through these irregularities.

Utilization of a primer in this surface might have partially filled out these irregularities, what would explain the highest variation in the group where it was applied. It should be emphasized that there were no statistical significant differences between them; however, there was a considerable increase in the standard deviation found.

All specimens presented adhesive failure in the interface. This happened because of the fact that bonding between cement and metal did not overcome the cohesive resistance of the cement.

Researches should be accomplished with the purpose of verifying the action of chemical, mechanical, and chemical-mechanical retention on the marginal leakage, color alteration and displacement of the esthetic facet or cement agents, searching for a smaller reduction in the remaining dental structure to receive a fixed prosthesis. This smaller reduction would allow higher preservation of the dental structures, which are better than any restorative material existing.

\section{CONCLUSION}

Based on the results achieved and after statistical analysis and discussion, it could be concluded that the best outcomes of retention were found for the sandblasted groups (JSP, JCP), regardless of the primer application.

Alloy Primer application was effective in the formation of chemical bonding between the tested resin cement and the cobalt-chrome alloy; however, this bond strength did not overcome the force of the micro-mechanical union reached by sandblasting with $100 \mu \mathrm{m}$ aluminum oxide.

All specimens presented adhesive failure at the resinmetal interface.

\section{REFERENCES}

1- Antoniadou M; Kern M; Strub JR. Effect of a new metal primer on the bond strength between a resin cement and two high-noble alloys. J Prosthet Dent 2000;84:554-60.

2- Eshleman J.R. et al. Retentive strength of acid-etched fixed prosthesis [abstract 153]. J Dent Res 1981;60(sp Issue A):349.

3- França RO, Muench A, Cardoso PEC. Resistência de união entre liga de níquel-cromo e cimentos resinosos. Rev Odontol Univ São Paulo 1998 Jul/Sep;12(3):267-70.

4- Howe DF, Denehy GE. Anterior fixed partial dentures utilizing the acid-etch technique and a cast metal framework. J Prosthet Dent 1977; 37(1):28-31.

5- Hulterstrom M, Nilsson U. Cobalt-chromium as a framework material in implant-supported fixed prostheses: a 3-year followup. Int J Oral Maxillofac Implants 1994; 9(4):449-54.

6- Kansu G, Aydin AK. Evaluation of the biocompatibility of various dental alloys: Part 2 - allergenic potentials. Europ J Prosthodont Restorat Dent 1996 Dec; 4(3):155-61.

7- Lin T, Chang H, Chung K. Interfacial strengths of various alloy surface treatments for resin-bonded fixed partial dentures. J prosthet Dent 1990 Aug; 64(2):158-62.

8- Matsumura H, Tanaka T, Atsuta M. Effect of acidic primers on bonding between stainless steel and auto-polymerizing methacrylic resins. J Dent 1997; 25:285-90.

9- Rubo JH, Pegoraro LF. Tensile bond strength of a composite resin cement for bonded prostheses to varios dental alloys. J Prosthet Dent 1995; 74(3):230-4.

10- Yoshida K, Kamada K; Sawase T; Atsuta M. Effects of three adesive primers for a noble metal on the shear bond strengths of three resins cements. J Oral Rehabil 2001; 28:14-9.

11- Yoshida K, Taira Y, Sawase T, Atsuta M. Effects of adhesive primers on bond strengths of self-curing resin to cobalt-chromium alloy. J Prosthet Dent 1997; 77(6): 617 - 20 